\title{
Modern Heritage Investigation and Conservation: A Case Study of Taiyanggou Block and Lvshun Industrial School Site
}

\author{
Liang Lang*, Shiyuan Wang, Hui Yu*, Jiuju Liu \\ School of Architecture and Fine Art, Dalian University of Technology, Dalian, China \\ Email: *langbright621@126.com, *yuhui4792@163.com
}

How to cite this paper: Lang, L., Wang, S.Y., Yu, H. and Liu, J.J. (2018) Modern Heritage Investigation and Conservation: A Case Study of Taiyanggou Block and Lvshun Industrial School Site. Journal of Building Construction and Planning Research, 6, 122-137.

https://doi.org/10.4236/jbcpr.2018.63009

Received: July 10, 2018

Accepted: August 24, 2018

Published: August 27, 2018

Copyright (c) 2018 by authors and Scientific Research Publishing Inc. This work is licensed under the Creative Commons Attribution International License (CC BY 4.0). http://creativecommons.org/licenses/by/4.0/

\begin{abstract}
Modern buildings and blocks in open port city, which are an essential part of the urban context, possess unspoken values of material properties and cultural resources for the urban future. According to the investigation of Taiyanggou Block and Lvshun Industrial School Site in Lvshun (China), this paper aims to discuss the understanding and conservation of modern heritage. Firstly, it interprets the opening of modern Lvshun and the formation of Taiyanggou Block to provide the fundamental knowledge. After a brief introduction of Lvshun Industrial School Site, the paper analyzes the problems in conservation practice and proposes countermeasures on heritage management and reuse strategy. Finally, it indicates that to conserve modern heritage means to preserve and to enhance their integrated values of space and culture in the framework of local development.
\end{abstract}

\section{Keywords}

Modern Heritage, Taiyanggou Block, Lvshun Industrial School Site, Military Property, Reuse Strategy, Integrated Conservation

\section{Introduction}

Open port city is the window of western culture transmission and the outpost of modernization in modern China. In addition, it is the pilot also and main body of the urban transformation. Under the influence of "West Learning", plenty of the buildings there appear typically non-native features, and become a unique type in the map of Chinese modern architecture. Those remains significantly constitute the urban context and turn into an important part of architectural heritage in China, with a great heritage value and a practical role unignorably. Compared with ancient heritage, the moderns mostly are live heritage with con- 
tinued functions, which tend to be an overlook of their significances. The constructive interruption and protective disruption took place from time to time. Therefore, it is necessary to strengthen the understanding, investigation, and conservation of modern heritage.

Modern Lvshun suffered much adversity, starting urban modernization via a forced opening during the leased period by Tsarist Russia (1897-1904) and occupied period by Japan (1905-1945). In the Sino-Soviet jointly built period (1945-1955) and the time before a full opening in 2009, it was under a semi-closed militarization management. Majority of modern buildings built in the colonial times were retained quite completely, avoiding the impacts of the Cultural Revolution and the fast urban expanding due to the military function of Lvshun, which formed the cityscape of unique characteristics. Lvshun Industrial School Site is located in Taiyanggou Block in Lvshun Kou City, referred to as Lvshun. It was built at the end of the Tsarist Russian rent time, experienced the replacements of the authorities and continued to use up to now. It is owned by the army and was named in the municipal protection list, but the current situation was unsatisfactory. As a modern architectural heritage formed in a particular context, its investigation and conservation study is of special significance.

The existing studies on urban architecture in modern Lvshun mainly focus on the urban construction history, blocks conservation, and architectural type features. Lina Zhou [1] summarized the evolution rule and motivation of urban space in modern Lvshun. Jianglin $\mathrm{Xi}$ [2] [3] interpreted the background and process of modern construction from a geopolitical perspective, and proposed a protection strategy referred to the historic partition of urban functions. Xutao Wen [4] advanced the concept and strategy of modern styles and features protection of Taiyanggou Block in terms of historic places, buildings, and urban facilities. Ling Qin [5] analyzed the emerging problems and the facing situations in the protection and development of Taiyanggou Block and gave solutions. Heng Wang [6] proposed protection and utilization strategies of historic buildings in Taiyanggou after a multiple evaluation. Shifen Li [7] concluded the form characteristics and the evolutionary history of styles of modern buildings in Taiyanggou. Haiping Lv [8] explored the features and its evolution of modern residence in Lvshun. To sum up, the existing studies mostly discussed the current situations of the protection of modern cities and blocks from macro and middle-level perspectives. The discussions of certain buildings built at that time do not go far enough, which means case studies from a micro perspective need further discussions. Taking the investigation and conservation analysis of Lvshun Industrial School Site in Taiyanggou, this paper aims to explore the understanding of certain modernization influenced urban heritage, as well as its protection and reuse strategy.

\section{Historical Evolution of Taiyanggou Block in Lvshun}

\subsection{Formation of Modern Lvshun}

Lvshun is on the southernmost tip of Liaodong Peninsular with seas surrounded. 
It possesses a geographical location, with Shandong Peninsular across the sea. At the beginning of Ming Dynasty, the royal government conducted migration in Liaodong region to open up wasteland, open maritime prohibition, and build new towns, during which Lvshun became an important fortress for coastal defense and a trading port. In 1880, the Ching government began to build naval harbor, fort barbettes, and shipyard in Lvshun to construct a military base [9]. At that time, the urban constructions mainly centered on a flat, off the east bank of Long River, embraced by Mount Baiyu and Mount Huangjin. On the other side of the river, scattered few settlements, straggled along the coast of West Port and down the south of Mount Anzi (Figure 1). Before the outbreak of the Sino-Japanese War in 1894, the interdependence of the harbor and the town in Lvshun began to take shape [10].

In Ching Guangxu 23 years (1897), Tsarist Russia forcibly occupied Lvshun port, after which they coerced a lease of Lvshun and Dalian via "Convention for the Lease of the Liaotung Peninsula". Then they started the urban constructions, dreaming of a military port in Lvshun and a commercial port in Dalian [11]. In 1901, the Commander of the Russian Pacific Fleet, Yevgeni Ivanovich Alekseyev, also the governor of the Kwantung Fortified Region 1), planned to develop Lvshun with a new town project on the coast of West Port, west of Long River. The construction of new town started soon after an approval from Tsar Nicolas II, but came to a halt when the Russo-Japanese War broke out in 1904. Tsarist Russia lost the war in 1905 and pulled out. Japanese Empire took charge of Lvshun, starting a colonial control for nearly 40 years. The Japanese continued the new town project of Tsarist Russia and completed it eventually. They called the new town "New City", correspondingly the areas east beyond the river was called "Old City". At this point, the modern pattern of Lvshun came into being (Figure 2).

\subsection{Modern Planning of Taiyanggou Block}

Now the new town established by Tsarist Russia and improved by Japanese Empire is called Taiyanggou, of which the current layout derives from the initial planning "Port Arthur New Town Planning" 2) (Figure 3). Though the main construction of Russia in Lvshun was for military purposes, it was not a simple partition of land for an easy control. Instead, the planning was carefully crafted design under comprehensive considerations for topography, hydrography, and the political demands.

In response to the orientation of the coast, the planning laid a fundamental grid with a westward rotation of 21 degrees and elected a space axis pointing to the Mount Anzi in the north and West Port in the south, which consists of landmarks, squares, and urban greens. The skeleton roads emanated from nodes of the axis to the surrounding areas symmetrically. Certain points of intersections of the streets grew to become urban squares in polygon or round shapes, connected with new accesses, shaping some secondary space nodes. On the west side of the planning land existed some barracks, whose arrangement enabled the 


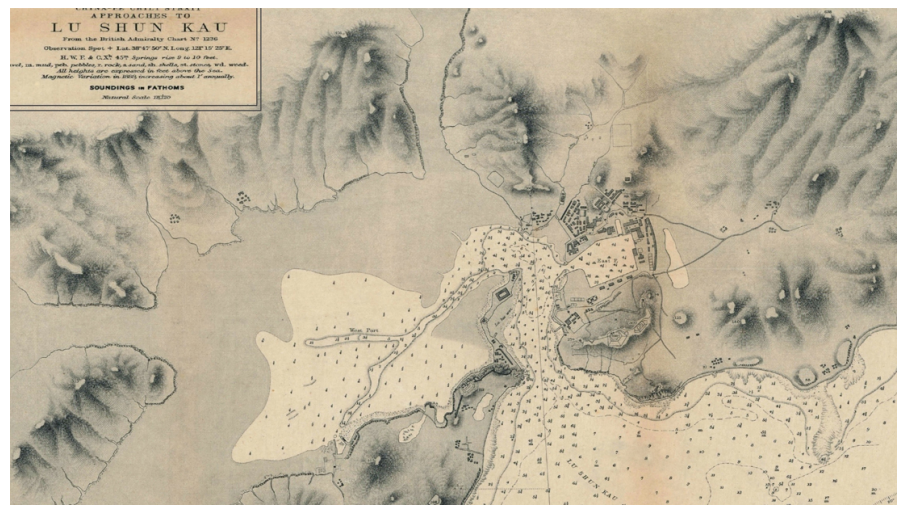

Figure 1. Map of Lvshun of 1896.

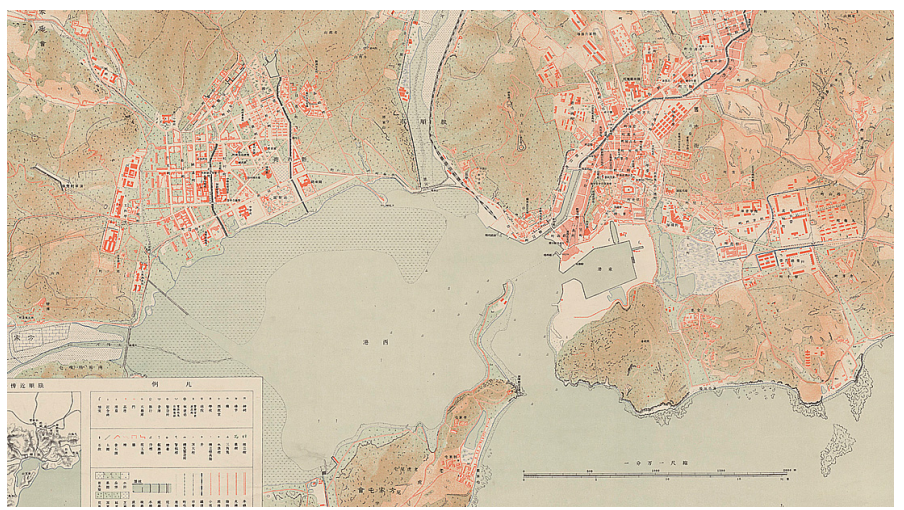

Figure 2. Map of Lvshun of 1918.

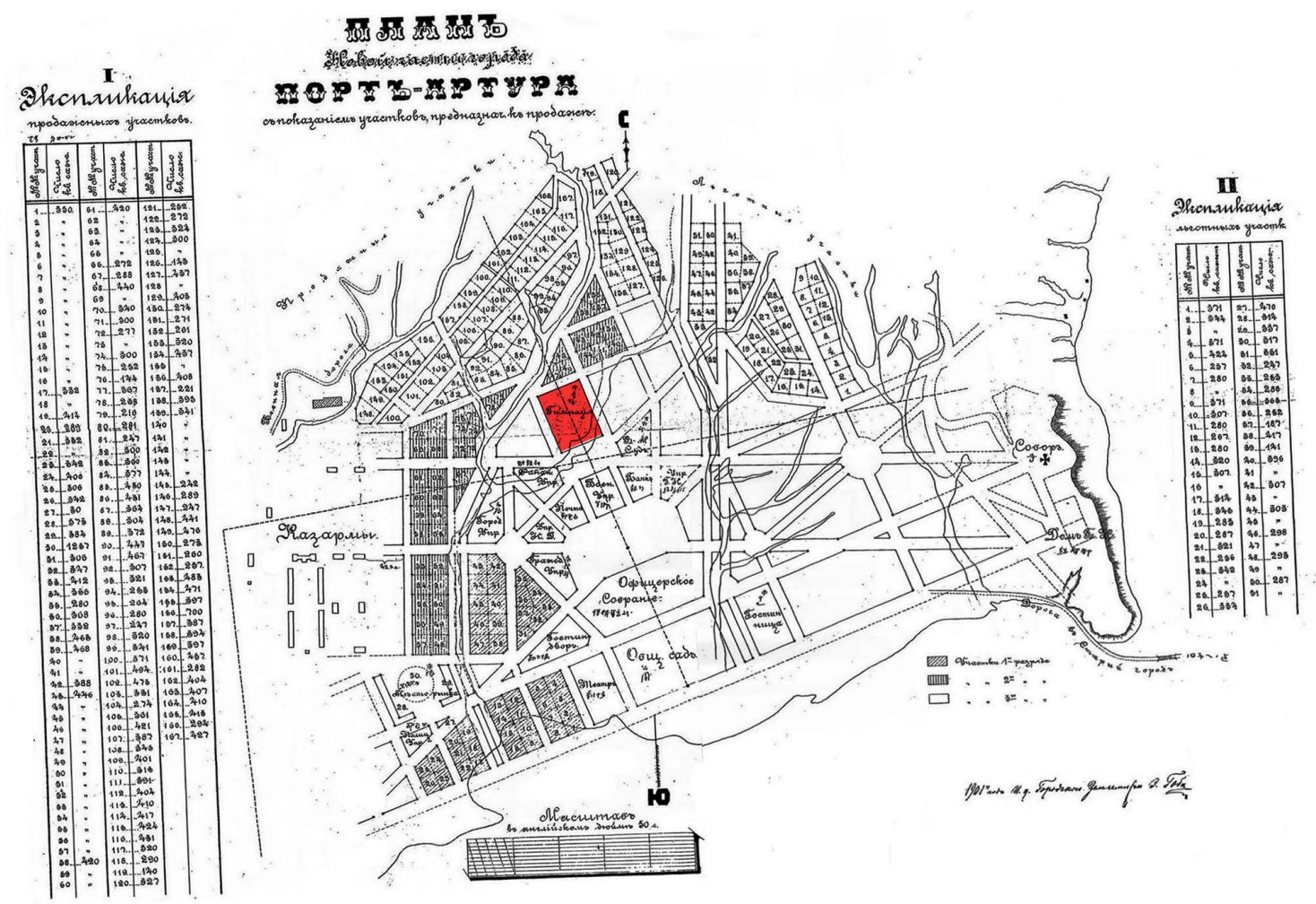

Figure 3. Port Arthur new town planning of 1901. 
part of the dominant grid a rotation. On the north, close to the mountain, the land partitions were random in harmony with geography. The planning also retained the two major steams down from the back mountains and turned them into waterscape running through the new town.

At the center of the new town and the southern waterfront, were administrative districts. Residential areas lied in the west and north. In the east was military district due to it was close to the existing military harbor. The core of the new town was a gathering plaza, surrounded by headquarter, court, post office, bank, and other public buildings. At the northern part of the urban axis, planned to build a school to separate the administrative area and the residential area, and an urban park at the southern part. Cultural and entertainment facilities such as the hotel and theatre were set in the coastal areas, as well as some high-level residential blocks for sale. Other level residential blocks were set on the west and north side. On the east and southwest side, the blocks would be for military installations.

Tsarist Russia only completed the primary stage of the new town project then got out of Lvshun. For lacking the experience of modern city construction and saving money, the Japanese adopted the original planning of Russia, which would be an economical and appropriate choice to rehabilitate the city immediately at the beginning of their occupation [12]. In "New City", the Japanese shrank the core square, wiped out some node connections to cancel the irregular blocks, and implement the new town construction. The layout and townscape of the new town area, now called Taiyanggou, remained largely unchanged, for Lvshun gradually turned to be a military city from the Japanese colonial rule until the subsequent power transitions.

\section{General Introduction of Lvshun Industrial School Site in Taiyanggou}

Lüshun Industrial School Site is located at the northern part of the urban axis of Taiyanggou (Figure 4), which is just the planned school in the Russian project, also is one of the first completed buildings at that time. The site covers an area of 1.4 ha. The schoolyard covers about $9400 \mathrm{~m}^{2}$. The total area of school building, counting one layer, is approximately $1720 \mathrm{~m}^{2}$. The main building sits in the center, with a relatively spacious front yard and a cramped back yard. There is an oval pavement in the center of the front yard, crowed trees around (Figure 5). The yard entrance is in the middle of the front fence, sitting on the urban axis. The building body presents a rotated "E" type on the plane of symmetry, horizontal expanded. On the low-pitched roof stands semicircular dormers and prominent chimneys. The façade is a typical classical style, three parts in both vertical and horizontal directions. The lower part of the façade is ashlars while the uppers is naked bricks in red with mortar fillings. All the windows are of roman arches, decorated with greyish white mouldings. The building structure is a mixture of masonry walls and wooden truss, covered by metal roofing (Figure 6-11). 


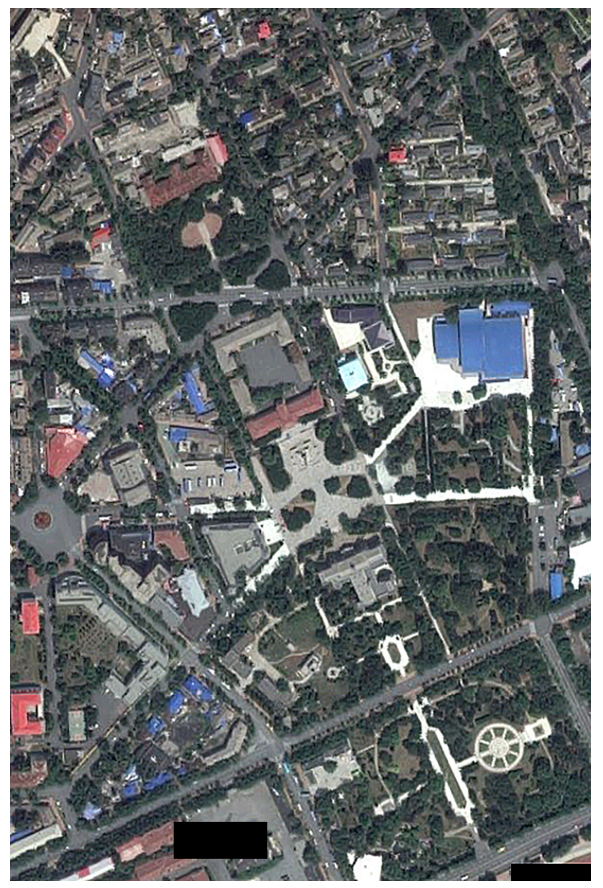

Figure 4. Location of Lvshun industrial school site.

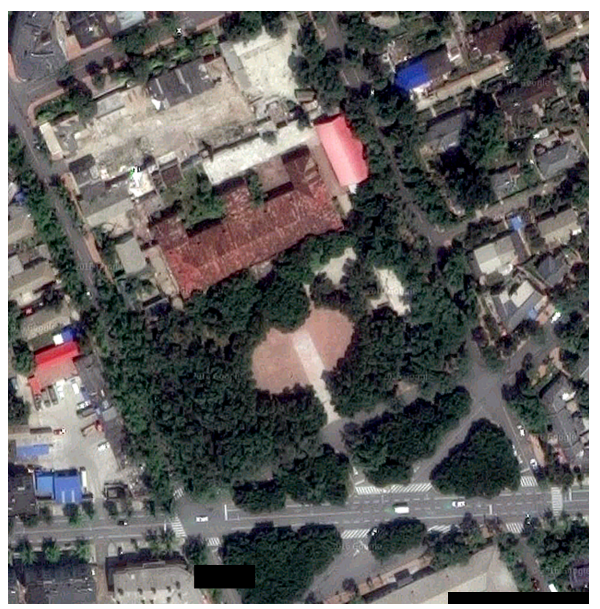

Figure 5. Satellite photograph of the site of 2016.

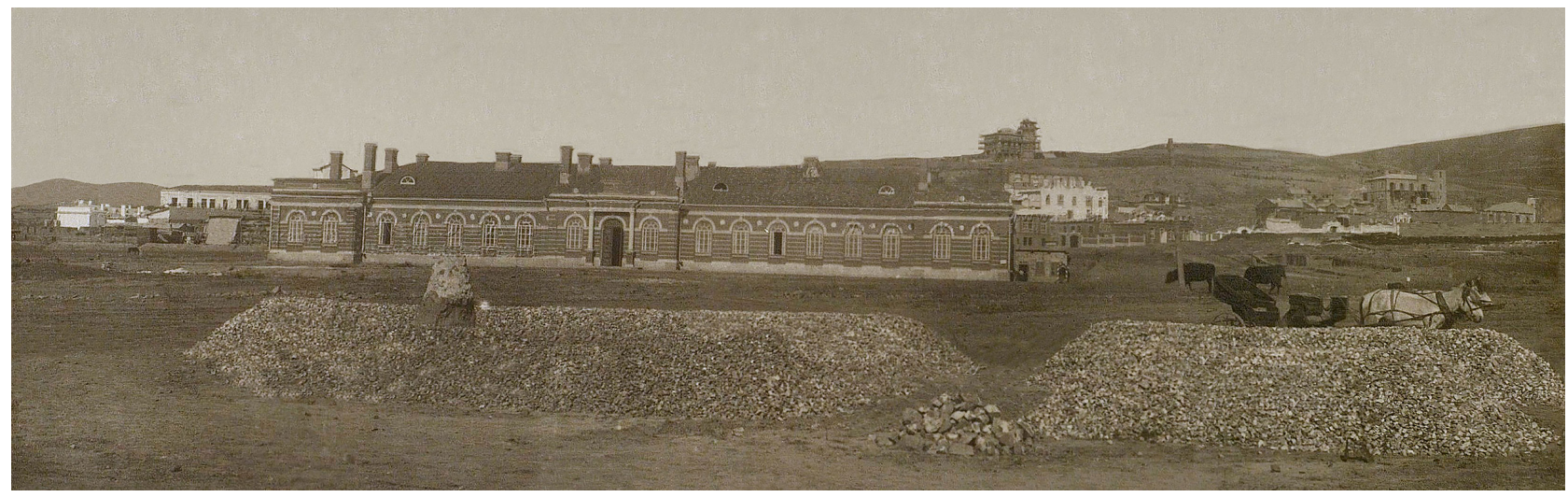

Figure 6. Picture of Lvshun Taiyanggou industrial school (Tsarist Russia vocational school) of 1903. 


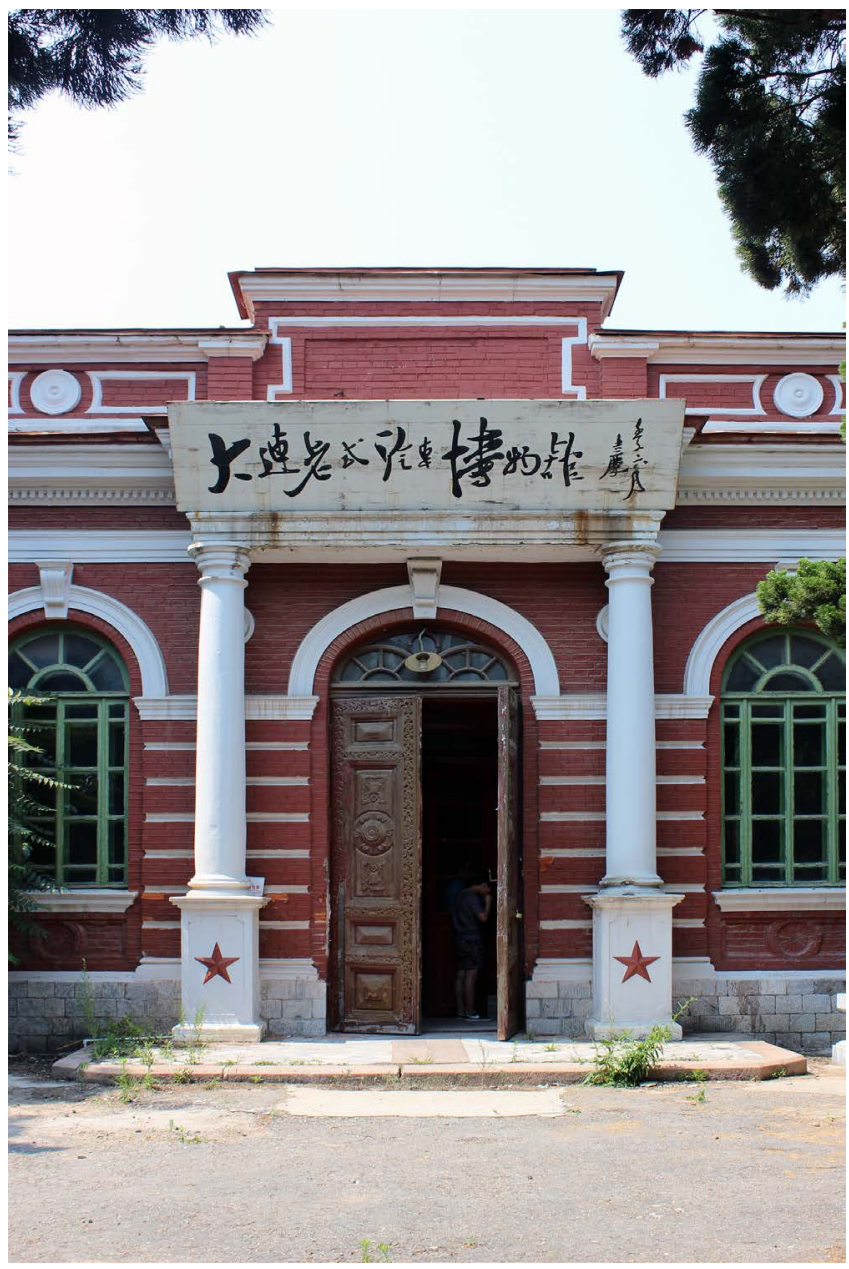

Figure 7. School main entrance.

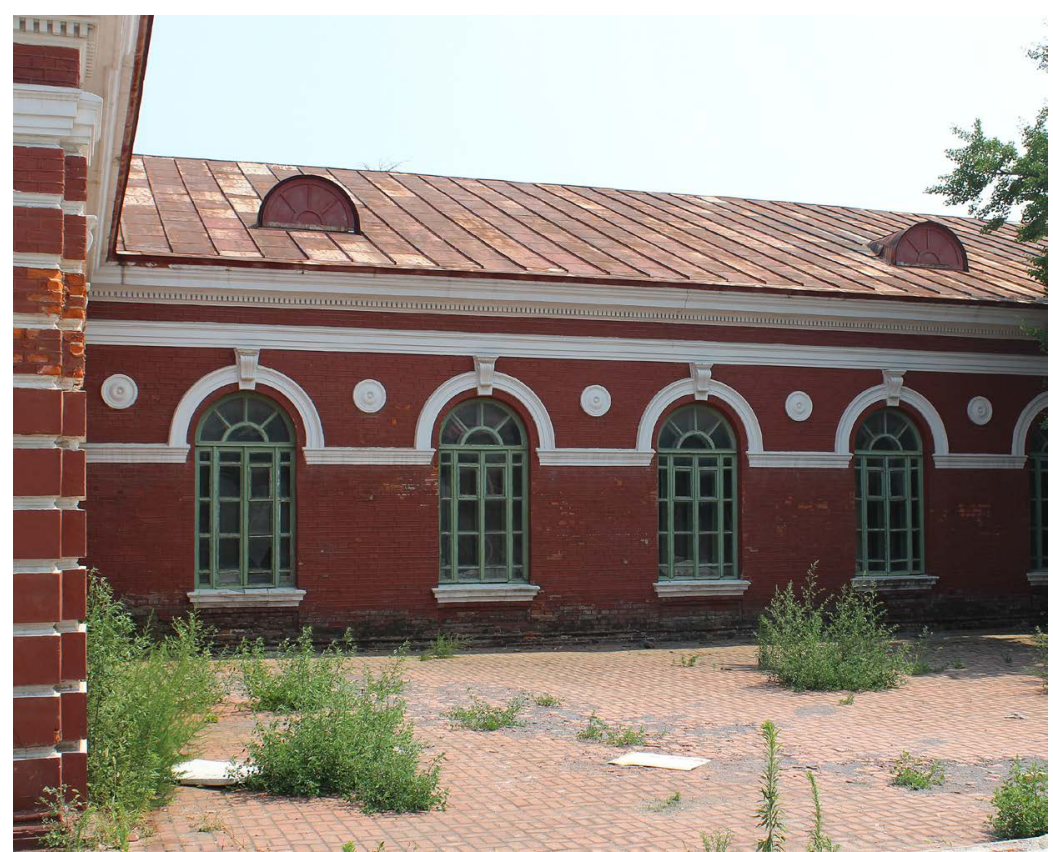

Figure 8. Concave section of the northern facade. 


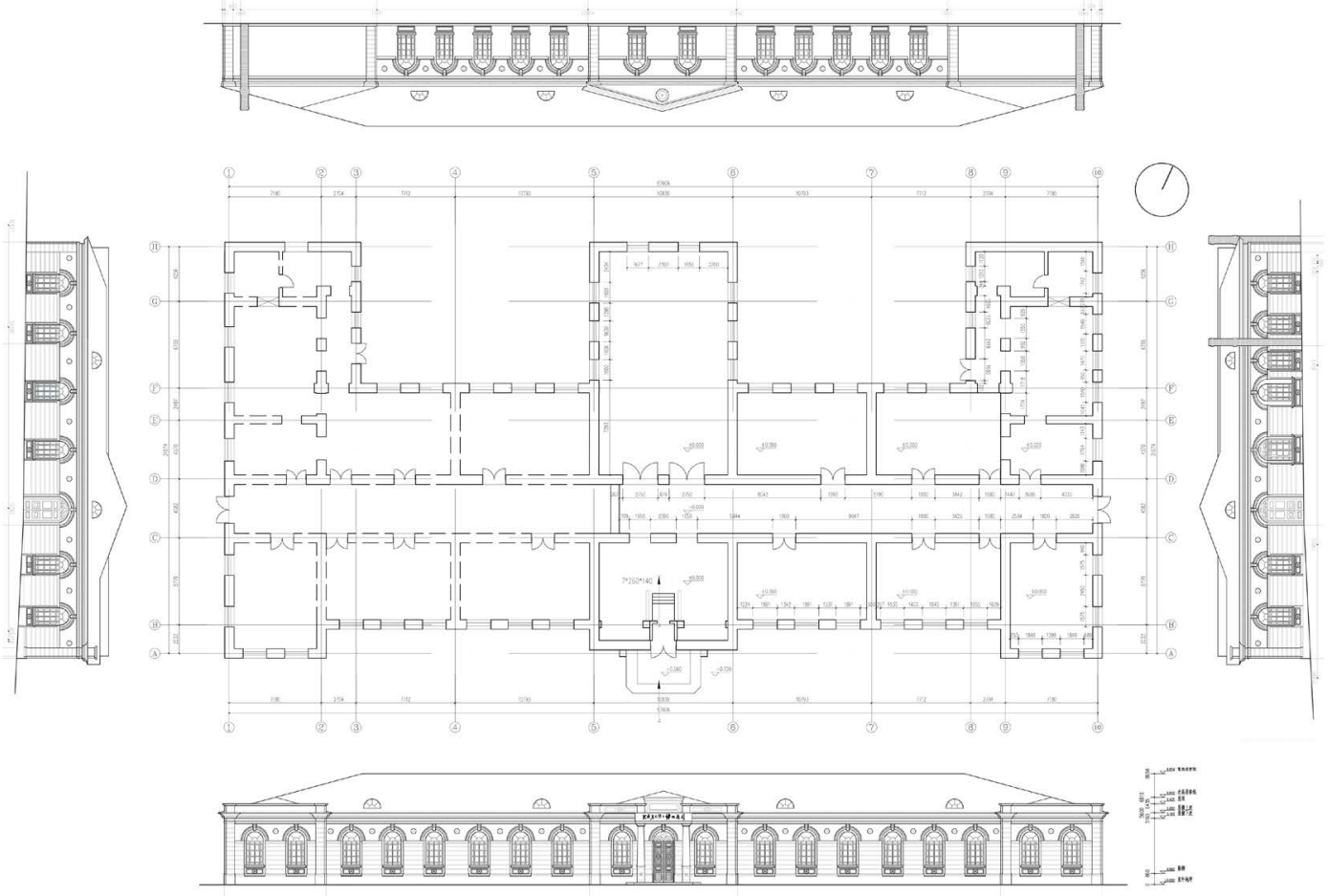

Figure 9. Drawings of the surveying and mapping of Lvshun Industrial School Site.

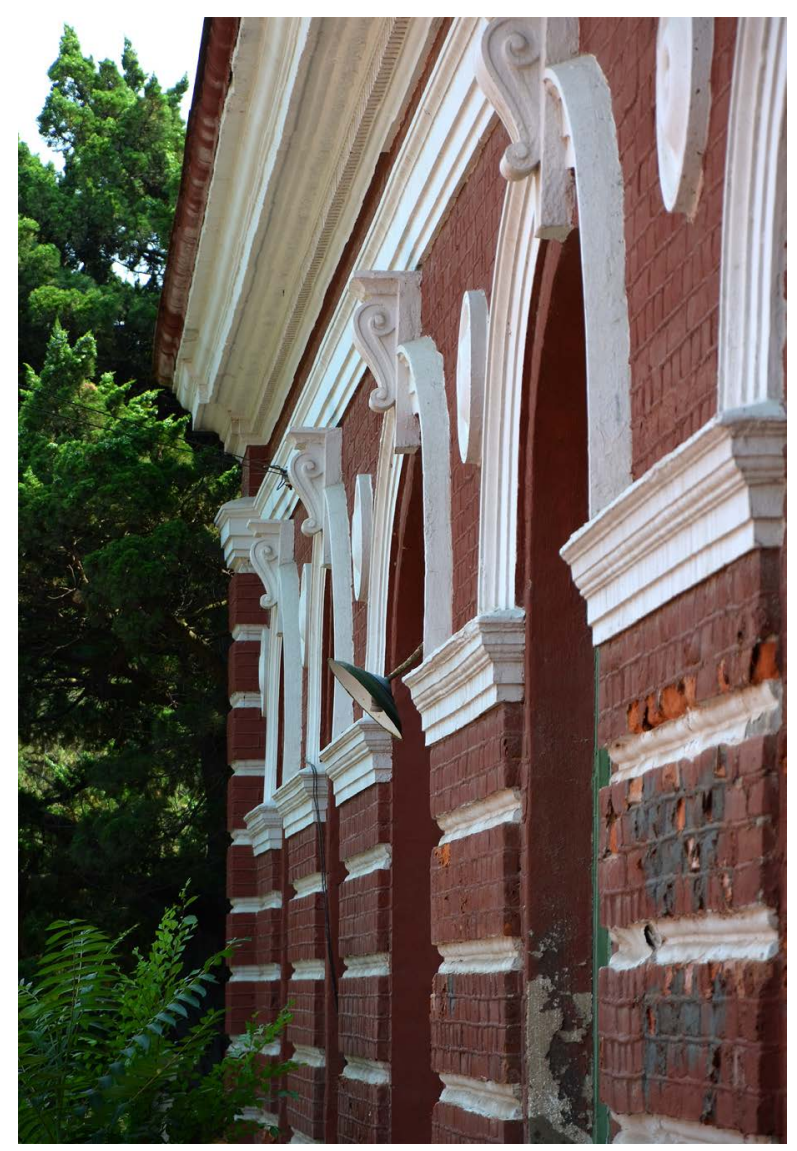

Figure 10. Decorative details of the mouldings. 


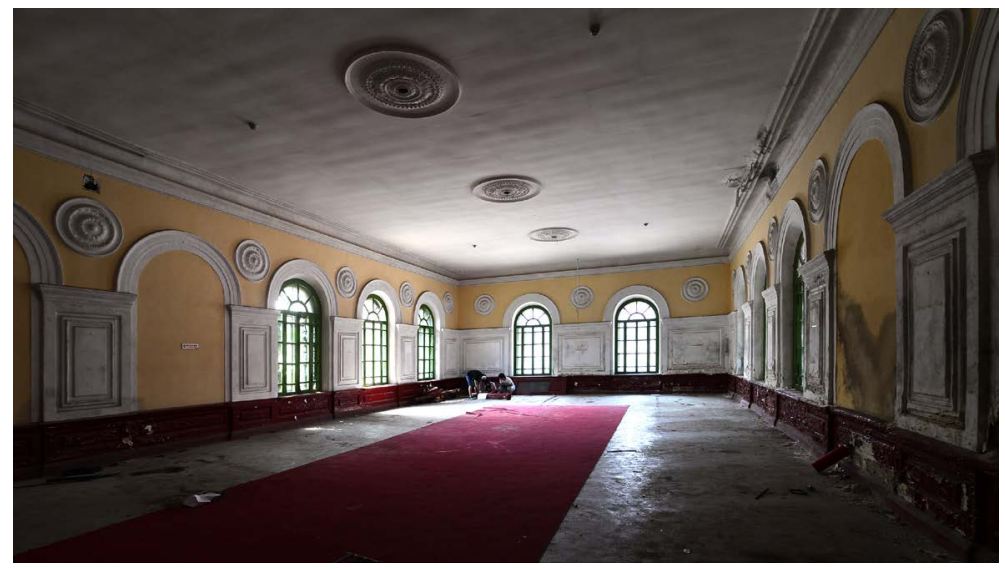

Figure 11. The central hall of the school.

In the past 100 years, the building usage has changed several times under the influence of urban revolutions, which could be divided into 3 stages: 1) In colonial era. In 1903, Kuantung Government of Tsarist Russia erected this building for a vocational school (Russian: Реальное училище) sponsored by national finance, schooling 5 years, setting up commerce, reserve and supplement sections to educate the middle and lower level colonial management employees. In 1905, Japanese troops changed it to the chamber of commissioned officer, a subsidiary venue of Kuantung Army Command after they fully occupied Port Arthur [13]. 2) In military use era. In 1945, Soviet Army stationed Lvshun after World War II and used it as Soviet trophy gallery. In 1955, the People's Liberation Army took over Lvshun and made it a military museum, which is the predecessor of the Military Museum of the Chinese People's Revolution founded in Beijing in 1958. In 1966, the military club directly under the political department of Lv-Da Garrison took in charge of it. 3) In commercial rent era. In 1977, Lvshun Military Museum closed after all the collections were sent to the Military Museum of the Chinese People's Revolution. Then the Lvshun Office of Dalian Real Estate Administration in Shenyang MAC, took over the regulation and lends it for business. In 2008, a merchant Xiangyang Liu rent it to exhibit his private collections of old cars and motorcycles and named it Dalian Old Cars $\mathrm{Mu}$ seum. For personal reasons, the museum closed in 2014 and left unused until now.

\section{Investigation of Lvshun Industrial School Site}

\subsection{Survey Findings}

Lvshun Industrial School Site was listed in the fifth group of Municipal Cultural Relics Protection Units on behalf of "Important Historical Site and Typical Building in Modern Times" in 2003 and the second group of Key Protected Architecture of Dalian in 2004. Despite having been put into legal protection list early, it received few effective protections and reuse in the commercial rent during the last decade, especially before 2008. "In chaotic managements, it was used as clothing factory, school building, restaurant, jade gallery, etc. Many lessees 
damaged the appearance and interiors for the purposes of their own just like to kill the goose that lays the golden egg" [14]. In 2008, the merchant Liu rented the site and invested in building maintenance and environment renovation at the start, which improved the conditions to a certain extent. He restored the inner structure and externals to the original appearance or the significant transformations alone the changes as much as possible, with few decorations necessary for indicators, turning it roughly what it would look like and what we saw today. The spacious rooms were ideal places to exhibit his automobiles without much alteration. However, the architectural conditions were far from the expectation of a good protection in the late of his rent. Some photos from tourists showed that it was easy to see moldy walls in different rooms inside and some squatters outside (Figure 12 and Figure 13).

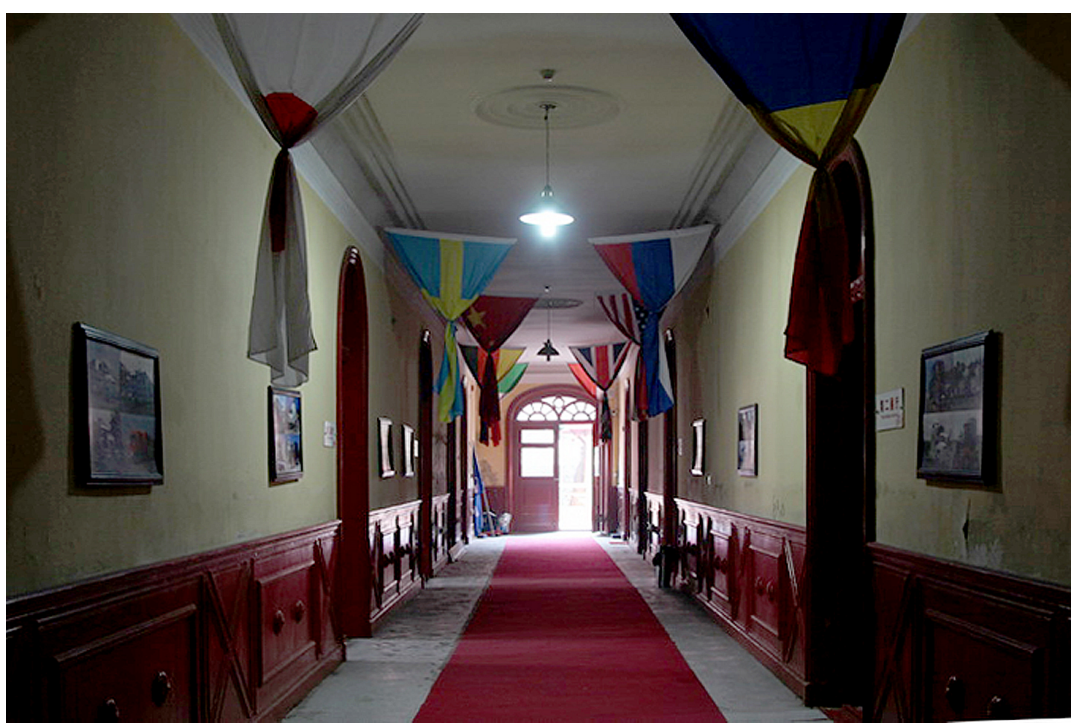

Figure 12. The corridor view of Dalian Old Cars Museum.

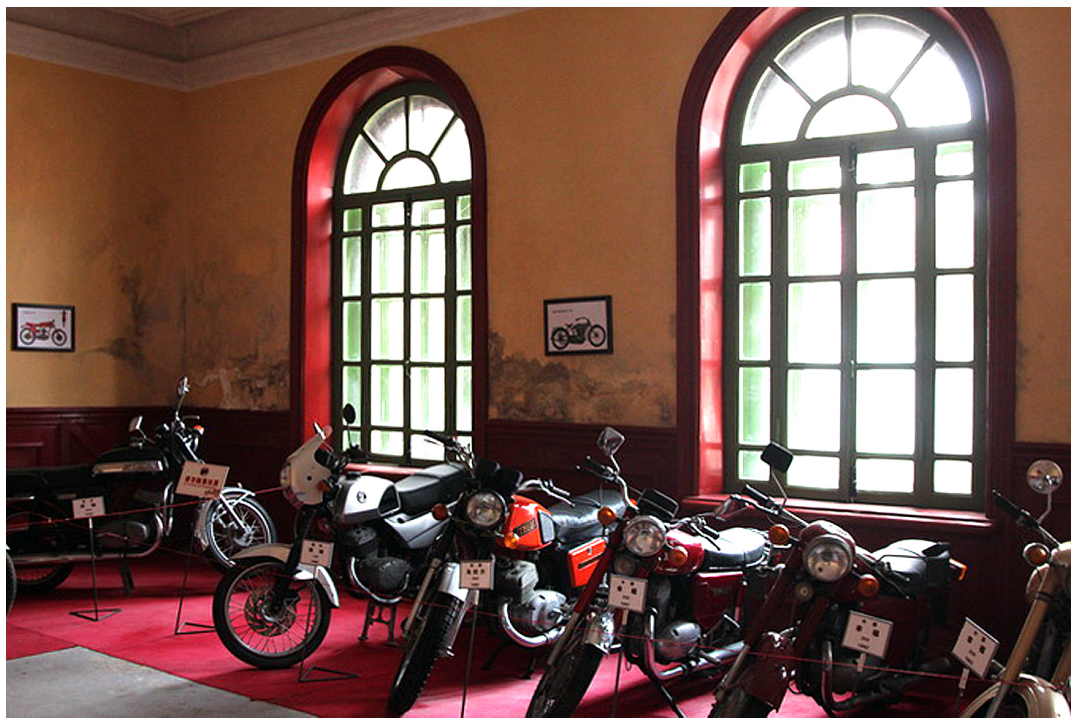

Figure 13. Moldy wall in the exhibition room. 
The site is vacant after the closure of old cars museum. The survey conducted on July 2015 gives some findings. There was a gap in the west side of the enclosure, from which anyone could easily get access into the yard. The food wastes and traces of picnic found in the grass assured the unattended situation. There was an additional structure in the back yard, apparently illegal. The door of the main building was locked but one could climb into the inside through a broken window on the east facade. In the main building, a wall placed on the west edge of the lobby divided the whole interior into two; the east part was the closed museum for old cars, the west part was rented to the others, which was closed and abandoned either. The improper partitions and deteriorative coatings indicated the destruction of authenticity and integrity inside the building. The yard was thickly forested with Dragon Juniper. In front of the east wing among the Dragon Junipers and locusts, there was a seven-pointed maple, which was rare in Dalian area, growing nicely, over 100 years old by inference. The survey also found some newer tiles and wrappings of pesticide left in the grass, showing that the site was not be abandoned completely and certain person might come to maintain it probably. Anyway, such measures of maintenance could not stop the declining and vandalism.

\subsection{Problem Analysis}

\subsubsection{The Indeterminate Subject of Responsibility}

The ownership and obligation of historical building are often complicated owing to the multiple changes of the managements and utilizations. This situation is more representative in Lvshun. In Taiaynggou Block, $37 \%$ of the land with its buildings is military properties. Since the foundation of New China, Lvshun Industrial School Site has always been a possession taken by the military. For lack of effectively integrated system suitable for military and local authorities, Lvshun Industrial School Site is no different to the other historical relics under two management systems in vague identity of whom to be in charge of the conservation. Due to the disjoined relationship between local authority, property owner and lessee, it is hard to ensure the accountabilities for the damage such as the illegal partition and occupancy, feckless maintenance and renovation.

\subsubsection{The Improper Reuse Strategy}

Despite a military port, Lvshun still is a tourist city with a great wealth of tourist resources, notably the historic and cultural landscape on behalf of modern historical relics. In Taiyanggou, there are about 800 historical buildings built in the Russian and Japanese colonial era left until now. Some of them got well preserved and became famous attractions. For instance, Lvshun Museum 3), and Kwantung Army Command Site Museum 4). With the transformation of being an old cars museum, Lvshun Industrial School Site joined the team of tourist spots. To the contrast of the others, it won few popularities. One of the main reasons is that there is no association between automobile culture and urban historical humanity, thus the local community does not identify the museum as 
one part of their lives, as well as the recognitions of tourists. From the tourism industrial planning point of view, the reuse strategy of the site neglected the foundation of urban culture and consumer phycology of tourists. From the urban development-planning point of view, the strategy is incomplete in the thinking of integrated conservation of the area and the possibility of public participation.

\subsection{Countermeasure}

\subsubsection{To Perfect the Management}

After the full opening of Lvshun from 2009, the urban functions got an improvement. However, due to the urban history, the military domain and the municipal control could not be separated easily. Aiming at an efficient approach to protect the historic buildings possessed by the military in Taiyanggou, Lvshun government developed a creative mode of its management. In 2015, Dalian Taiyanggou Cultural Industrial Development Co., Ltd. was founded. In the same year, Taiyanggou Cultural Industrial Park Management Committee was set to rent the whole building properties in Lvshun those under the jurisdiction of Dalian Real Estate Administration in Shenyang MAC, which produced a "Lvshun Model" for the local authorities to manage the military-possessed heritage [15]. Lvshun Industrial School Site now was rented to the local government, who exercises the management function instead of the military, achieving an unification of operation, management, and monitoring. The perfection of the management to the urban heritage of military properties will help to clarify the responsibilities and the duties, standardizing the conservation practices.

\subsubsection{To Integrate the Resources}

There are 42 Cultural Relics Protection Units of different levels in Taiyanggou Block. Of these, 5 of National Level, 1 of Provincial Level, 8 of Municipal Level, and 2 of District Level, as well as other 337 historic buildings of general protection in law. It is rich in heritage resources. After taking over the heritage of military properties, Lvshun Government paid high attention to the protection and revitalization of Taiyanggou Block. They established the basic principles and cultural industry orientations for the heritage conservation and reuse [16]. Under the guidance of the policies and the control of the conservation planning, the historic environment improvement, the inadequate function replacement, and the future development orientation of Taiyanggou Block as well as the historic buildings in it, should establish contacts with each other, tapping the potentials by the effect of modern heritage cluster. Moreover, based on the enhancement of the cultural identity understanding, it is essential to integrate the protection to the framework of urban conservation, regeneration, and development, realizing the transformation of the combined value of space and culture, as well as the wedging into social life.

\subsubsection{To Build a Brand}

During the last decade, Taiyanggou Block was not given much advance publici- 
ty. Seldom people outside of the city heard of it. It is much necessary to elevate the influence and visibility of the historic block and buildings. Thus, branding is important for the conservation and revitalization, which could bring more supporting policies and funds, as well as the tourism revenue. The similar cases are Xintiandi Block and Tianzi Lane in Shanghai, The Southern Gong and Drum Lane in Beijing, China Lane in Chengdu and so on. All of these historical blocks have become business cards and urban brands of their cities, achieving a balance between protection and exploration. To build the brand of Taiyanggou Block needs not only a historical environment rearrangement in pursuit of an iconic style of its characteristics, but also a planning of cultural and economic activities, such as to hold tourism festivals in themes periodically, or to bring in art workshops and creative agencies to foster the relevant cultural industry. In addition, the well-preserved block form and building features enable Taiyanggou Block a perfect location to make films of modern history theme, from this point of view, to cultivate the film and television production as well as the related services is another approach to extend the publicity of the block and improve its brand impact.

\subsubsection{To Reevaluate the Reuse}

Due to historical reasons, modern Lvshun was a military-related city, born of a military port and subject to military purposes. In Taiyanggou Block, most of the explorations of historic buildings are concerned with military theme of different periods. The corresponding representations demonstrate the urban history and cultural landscape. For Lvshun Industrial School Site, to improve the unsatisfying conditions and make full use of its values, a reevaluation of the reuse and its meanings to the public is of great necessity, especially in the modern view of conservation concept that "to preserve is an approach, the meaning is the goal" [17]. The architectural spaces inside and outside are adaptive and the building site is easily accessible. Taking urban history, block development orientation, and the building conditions into account, it could be a museum of certain military subject as it was once before, being one new stop of the military theme tour in Taiyanggou Block. It could be an exhibition area on modern social life in Lvshun but not automobiles, which would also be harmony with the others and become another interest of tourists here. Either, it could be reused as a theme restaurant, a pavilion or leisure facilities to be a beneficial complement to the public service of the urban tour. Moreover, it could turn into a community center to serve the local residences daily, attaching the historic environment to the local community, realizing a community identity of the reuse and public participation in conservation.

\section{Conclusions}

The modernization of open port city in China is often accompanied with colonization. The modern construction in pursuit of colonial interests objectively accelerated the transformation of urban architecture in modern China. For the 
geopolitical significance, Lvshun was passively involved in the opening and founding under the guidance of military strategy, and realized the spatial formation via the picture of a modern city painted by the western colonialists. The political and military intentions always dominated the process of urban modernization in Lvshun, shaping a special historical context, and making a significant impact on the urban construction and urban culture.

Lvshun Industrial School Site, an educational building built at the beginning of $20^{\text {th }}$ Century, completed the public service of the city as one fundamental type of modern urban architectures. The architectural layout and features were born of a common style of European Classicism and Eclecticism, mirroring the concept of the colonial construction and the orientation of the cultural value, documenting the dissemination and translation of the culture of the western architecture in modern times. The spatial forms and scales had strong adaptability to meet the different needs of the changing functions. All this built up the value of Lvshun Industrial School Site as modern heritage.

The values of modern heritage, being a material asset and a cultural resource for the urban future, are self-evident. To preserve the heritage of modern time is of the equal importance to the previous era. The case of Taiyanggou Block and Lvshun Industrial School Site indicates that the conservation of modern heritage is full of challenges. They lie in not only how to raise awareness, carry out assessment, explore methods, and implement reuse, but also how to identify them in a dialectical concept of history and value, and to explore an appropriate way of protection and regeneration in a social project integrated with political, economic, and cultural strategies, as well as the local development. Therefore, to identify the physical environment and the social memory of modern heritage would be an essential job to its conservation profession.

\section{Funding}

Supported by the Fundamental Research Funds for the Central Universities of China (No. DUT17RW112). The Project of Dalian Academy of Social Sciences (No. 2016dlskyb019).

\section{Notes}

1) Kwantung (Russian: Квантунская область), is a leased territory on the southern tip of Liaodong Peninsular in Northeast China from 1898 to 1945, including the two important military and economic port Lüshun Kou (Port Arthur) and Dalian (Port Dalny) which were successively leased to Tsarist Russia and Japan Empire.

2) Port Arthur is the English name of Lvshun, referred by the British, from a Royal Navy Lieutenant who surveyed the harbor in 1860. The Russians and other Western powers adopted it from that point on.

3) Lvshun Museum was established in 1915, and was called Man-Mongolian Property Gallery of Kuantung Capitania at that time. The main building was 
completed in 1918 and the name was changed to Kuantung Capitania $\mathrm{Mu}$ seum. In 1934, it was renamed as Lvshun Museum. In 2006, it was rated as Important Heritage Site under State Protection.

4) The main building of Kuantung Army Command Site Museum was erected in 1903 as the artillery department of Russian Kuantung Army. It was turned into Kuantung Capitania Ministry of Army in 1906 and Kuantung Army Command in 1919 by Japanese colonial government. In 2013, it was rated as Important Heritage Site under State Protection.

\section{Conflicts of Interest}

The authors declare no conflicts of interest regarding the publication of this paper.

\section{References}

[1] Zhou, L. (2013) A Tale of Two Urban Areas: The Evolution of Port Arthur's Modern Urban Space (1880-1945). M.Arch. Dissertation, Shenyang Jianzhu University, Shenyang.

[2] Xi, J., Yu, B. and Wang, J. (2016) Modern City Construction of Lvshun from Perspective of Geopolitics. Journal of PLA University of Science and Technology (Natural Science Edition), 17, 350-355.

[3] Xi, J., Yu, B. and Du, C. (2016) A Study about Lvshun's Dual Attributes and the Conservation Measures and Its Heritage. New Architecture, 5, 34-37.

[4] Wen, X. and Lu, W. (2002) Conception of Protection and Recycle for Modern Architecture Heritage. Journal of Dalian University of Technology (Social Sciences), 23, 68-72.

[5] Qin, L. (2016) Countermeasure Study on the Protection of Taiyanggou Historic Culture Blocks in Lvshun. In: Dalian Institute of Modern History, and Japanese and Russian Prison Site Museum in Lvshun, Ed., Dalian Modern History Study, Vol. 13, Liaoning People's Publishing House, Shenyang, 429-442.

[6] Wang, H. (2014) The Research on Comprehensive Evaluation and Protection and Utilization of Historical abd Cultural Blocks: A Case Study of Lvshun Taiyanggou. Territory \& Natural Resources Study, 2, 78-82.

[7] Li, S. and Liu, Y. (2014) The Form Style Analysis of Modern Architectures in the New District of Lvshun (Arthur Port). Chinese \& Overseas Architecture, 9, 91-94.

[8] Lv, H., Zhou, L. and Li, J. (2015) The Study of Modern Residence in Lvshun under Influences of Foreign Civilization. Journal of Shenyang Jianzhu University (Social Science), 17, 8-12.

[9] Dalian Local Chronicles Compilation Committee Office (ed.) (1987) Dalian City. Tianjin People's Publishing House, Tianjin.

[10] Liu, G. (2006) Lvshun Is the Earliest Modern City in Dalian. In: Dalian Institute of Modern History, and Japanese and Russian Prison Site Museum in Lvshun, Ed., Dalian Modern History Study, Vol. 3, Liaoning People's Publishing House, Shenyang, 400-409.

[11] Dalian Office of Local Chronicles (ed.) (2004) Dalian Records: Urban Construction. Local Records Publishing House, Beijing.

[12] Jiang, Y. (2013) Dalian Open Port and Founding. Dalian Publishing House, Dalian. 
[13] Sun, Y. (2012) Lvshun Military Museum Site. Dalian Daily, Dalian, A14.

[14] Che, C. (2010) Old Building, Rational Utilization Is the Best Protection, Dalian Daily, Dalian, A7.

[15] Lvshun Kou Municipal Government of Dalian (2016) Government Work Report of Lvshun Kou in 2015.

http://www.dllsk.gov.cn/zwgk_ClassNews.asp?newsID=61466\&classid=5

[16] Yu, H. and Zou, H. (2016) Characteristic Town, Historical Culture Attracted Guests All Around. Dalian Daily, Dalian, A3.

[17] Viñas, S. (2012) Contemporary Theory of Conservation. Tongji University Press, Shanghai. 